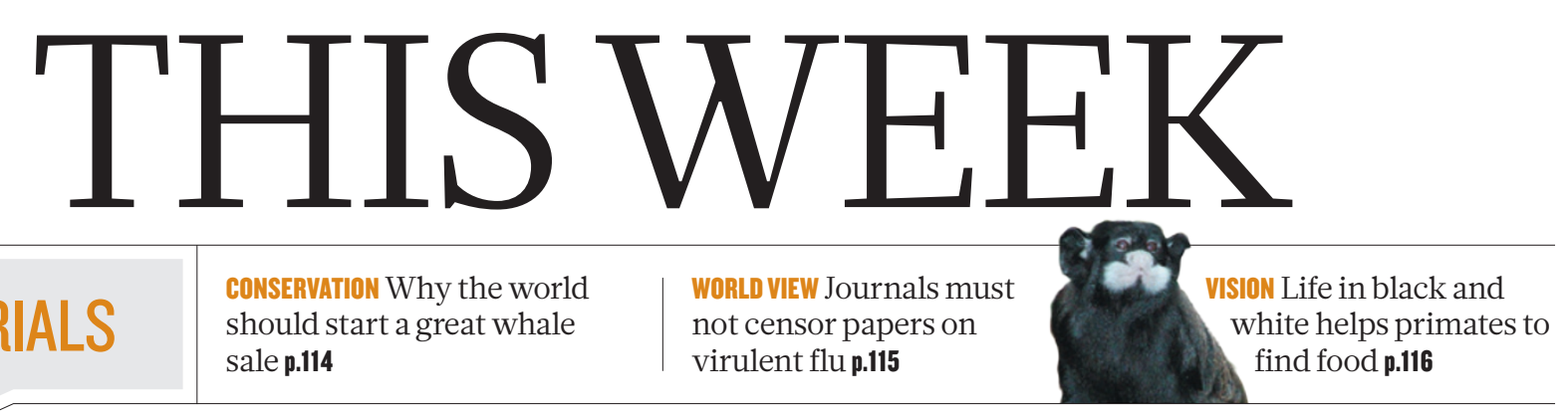

\title{
Get tough on nuclear safety
}

\section{A refreshingly frank and forward-looking report on the safety of French nuclear power plants in the wake of Fukushima should spur other countries to take a hard look at regulation of their own reactors.}

$\mathrm{T}$ The Three Mile Island and Chernobyl nuclear accidents each prompted profound rethinks of safety requirements. But as the incidents slipped into history, the nuclear industry, regulators and governments tended to revert to reassuring refrains that atomic energy was once again safe and in expert hands.

So it is probably too early to be confident about the impact of the Fukushima accident in Japan last March. But it is clear that, as the defences at the Fukushima Daiichi power plant crumbled, so too did the fundamental dogma of modern nuclear safety: that a series of back-up and redundant safety systems, combined with physical defences strong enough to resist expert estimates of external threats, was enough to make impossible a catastrophic meltdown and release of radioactivity into the environment.

As the first anniversary of the disaster approaches, and supporters and opponents of nuclear power prepare to use it to underscore their positions, will Fukushima mark a turning point for the nuclear enterprise, or will industry return to business as usual?

André-Claude Lacoste, head of France's Nuclear Safety Authority (ASN) in Paris, suggested at a press conference last week that things have already changed. "There will be a before and an after Fukushima," he promised.

Is he right? Some in industry will always oppose the costs of tougher regulation, and shortsighted or ideological politicians and companies will continue to insist that a repeat of Fukushima is impossible in their own backyards. But many in the nuclear industry were genuinely and deeply shocked to see at Fukushima a sequence of events that they believed impossible. The world's main nuclear operators have an interest in establishing the causes of the disaster and learning the lessons they know too well that if another major accident were to occur, then in many people's eyes the already-struggling industry would be finished.

The World Association of Nuclear Operators, for example, has stressed the need for its members to respond properly to Fukushima, and has beefed up its own inspection and oversight of plants (see Nature 472, 274 and http://doi.org/hj5; 2011).

So to France, the world's leading user of nuclear power and arguably the nation with the most to lose from a global rejection of it. Last week, the ASN released a report announcing a sweeping safety upgrade to all the country's reactors (see page 121). The planned multi-billioneuro improvements are part of a programme of tests to assess how well French reactors would stand up to extreme events, and how prepared plants are to deal with a major accident. The ASN's report is written with stunning candour, stating plainly that a loss of coolant or electricity could, in the worst cases, see meltdowns at reactors in hours. It also lists many shortcomings found during 'stress tests', in which some safety aspects of plants were found not to conform to existing standards.

Critics will wonder why the ASN didn't spot these problems earlier, given that it is responsible for regulating the plants. Others will question how the authority can reconcile its statement that France's reactors are fundamentally safe with its insistence that they must be upgraded on safety grounds. But it would be a mistake to penalize France for listing its nuclear shortcomings, especially when other nations seem less enthusiastic about publicly discussing problems with their own reactors and regulations. The French report makes for a breath of fresh air in a
"It would be a mistake to penalize France for listing its nuclear shortcomings." tive of their perceived vulnerabilitymends that all reactors, irrespecsafety systems, with control rooms, generators and pumps housed in bunkers able to withstand physical threats far beyond those that the plants themselves are designed to resist.

There will, rightly, be scepticism about whether France will ultimately implement the new measures. The bunker concept may prove technically difficult, and Électricité de France - the operator of the reactors - would need to pay for systems that some in the company will probably feel are an expensive luxury.

Whatever happens in the long term, the French plans have an immediate benefit: they raise the post-Fukushima safety bar for other countries. Those governments, regulators and companies that have yet to propose anything close to such far-reaching measures must now explain why not.

\section{A long stretch}

\section{The UK government hopes to squeeze even more out of science - without paying a penny extra.}

$\mathrm{D}$ avid Willetts may not be familiar with the film Jerry Maguire, in which Tom Cruise yells: "Show me the money!" But the UK science minister has been on the receiving end of a number of similar quips this week.

By most measures, the United Kingdom has always achieved greater research output than might be expected from the amount of government funding its science base receives. Last week, in a speech to the London-based think-tank Policy Exchange, Willetts said that he wants to stretch this relationship even further.

For starters, he wants the number of British universities rated among the world's top 100 to grow from the current figure of 